ARTICLE

Received 20 Feb 2017 | Accepted 26 Jun 2017 | Published 8 Aug 2017

DOI: $10.1057 /$ palcomms.2017.76

\title{
Exploring the cultural dimensions of environmental victimization
}

Matthew Hall ${ }^{1}$

ABSTRACT Arguing from a cultural victimological perspective, this article makes a case for the wider utilization of restorative justice and mediation-based approaches as a means of providing alternative or parallel justice mechanisms for both human and nonhuman victims of environmental crimes and broader environmental harms. Traditional criminal justice mechanisms, it is argued, are fundamentally ill-equipped to identify, prosecute and sentence in a manner proportionate to the full range of environmental victimizations emanating from many environmental crimes or other pollution events. Radical and critical criminological perspectives, it is argued, have only gone so far in conceptualizing this broader form of victimization, especially as it pertains to non-anthropomorphic aspects of the ecosystem. In contrast, the cultural understanding of victimhood has a more constructivist, dynamic character representing developing traumas and emphasizing the benefit to human victims of being officially acknowledged as such. It also gives such victims the opportunity to present "accounts" of their harm. Such characteristics, it is argued, better reflect the reality of environmental victimization and, in so doing, point towards a more central place for mediational and restorative justice mechanisms within the environmental sphere. That said, it will also be demonstrated that restorative justice and mediation mechanisms-despite bringing numerous advantages to human victims in terms of their perceptions of procedural justicehave as yet failed to adequately incorporate notions of ecological and species justice. Moreover, the present state of research in the area of environmental alternative dispute resolution is woefully lacking. The article, therefore, concludes with a call for more development of the cultural approach by green victimologists generally, as well as a focus on testing and developing restorative justice in this area in particular.

\footnotetext{
${ }^{1}$ University of Lincoln, Lincoln, UK Correspondence: (e-mail: mhall@lincoln.ac.uk)
} 


\section{Introduction}

his article sets out to bring together two distinct themes, which have until now been considered largely in isolation from each other within discrete branches of criminological discussion. On the one hand, in the victimological field, commentators have noted a marked shift in recent years towards a more culturally informed approach to the study of criminal (and other) victimizations. Such work has been characterized by the recognition of wider forms of harm, suffering and trauma coupled with the growing acceptance that victimization often constitutes a dynamic, evolving process rather than a static or discrete "event" (McGarry and Walklate, 2015). Concurrent with the development of these ideas, the steady rise of green criminology has proceeded apace in the last decade. Coalescing in the early 1990 s as a somewhat peripheral field of criminological enquiry (Lynch, 1990), green criminology has now achieved a significant degree of maturity and acceptance within broader criminological discourse. This is evidenced not only by the present special issue, but by the growing range of books, articles, edited collections and conferences dedicated to green criminological thought (see for example Potter et al., 2016).

The core argument put forward by this article is that the two apparently distinct avenues of debate set out above are in reality heavily interrelated and, as such, there is much to be gained from marrying the two. Specifically, this article will draw on cultural victimological principles to argue that traditional criminal justice solutions are often ill-suited to responding in a manner that fully acknowledges the broad range of environmental victimizationsto humans, nonhumans and to the environment itself-which follow on from environmental crimes and other harms. On the contrary, it will be argued that a cultural understanding of environmental victimization points more readily towards restorative justice and mediation-based mechanisms as a response to such harms and as a means of adequately reflecting the impacts of a fuller array of environmental victimizations. As such, it will be concluded that green criminologists need to engage fully with culturally derived ideas of harm if progress is to be made towards a more robust response on behalf of society to this kind of victimization.

In developing the above ideas, this article will discuss the development of "green victimology" before moving on to argue that the application of traditional models of criminal justice (and, often, civil and administrative justice) regimes in many jurisdictions neither encompass within their procedure, nor reflect through their outcomes, the full scale of environmental victimization or the dynamic character of the traumas involved. Although the development of radical and critical victimologies have to some extent refocused attention on the harm caused to victims rather than on positivist legal constructions of environmental crime, it will be argued that such developments have not gone far enough to reflect a less anthropocentric conception of victimhood, which is also dynamic in character. The article will then introduce the development of cultural victimology and explain how this largely constructivist understanding of victimization seems to reflect more readily the characteristics of environmental victimization as it impacts upon humans, nonhumans and the environment itself compared with the more legalistic categories of harm recognized by criminal (and other) justice processes. In so doing, it will be argued that a more restorative or mediation-based process may facilitate a fuller acknowledgement of the harm done to environmental victims, with the possibility then opened for that system to offer more in the way of practical and symbolic redress.

\section{Greening victimology}

For some time, the detailed study of environmental victimization trailed behind the vanguard of green criminological discussion. Early contributions in this area relied somewhat on traditional notions of criminal victimization, as in the following definition of "environmental victims" offered by Williams (1996):

"those of past, present, or future generations who are injured as a consequence of change to the chemical, physical, microbiological or psychosocial environment, brought about by deliberate or reckless, individual or collective, human act or omission" (p. 35)

As well as restricting such victimization to legally proscribed activities, this definition is typical of the scant green victimological literature of the time in that it is also entirely anthropocentric: failing to take account of the harms perpetrated against nonhuman animals as a result of environmental crime or harm.

It is only relatively recently that so-called "green victimology" has asserted itself as a subject of dedicated study (Skinnider, 2011; Hall, 2013). The development of this distinct literature exposed the challenges faced by most criminal justice systems across the world in relation to victimization deriving from environmentally destructive activities or omissions. Broadly put, the crux of this challenge lies in the fact that the characteristics of environmental victimization are often at odds with the standard approaches to crime and harm taken by these systems. This leads to such harms either not being recognized as criminally perpetrated at all or, if they are so recognized, the mechanisms of justice in place are not sufficiently calibrated to adequately investigate and prosecute such harms, nor to reflect their severity in terms of sentencing outcomes.

We can draw on a number of examples to illustrate this apparent mismatch between the features of environmental victimization and the forms of harm criminal justice processes more routinely deal with. First, environmental crime often affects large groups of victims: including human and nonhuman animals. The concept of mass or community victimization is still difficult for many justice systems to assimilate, recalling of course that most such systems around the world are still struggling to incorporate individual victims of traditional crimes, where matters such as causation are fairly clear cut (Kirchengast, 2016). Furthermore, because the harm caused by environmental crime tends to be diverse and long-term, these systems tend to find it difficult to account for all the negative consequences of a given environmentally destructive activity. This is due to limits of investigatory resources, time and difficulties in demonstrating causation between polluting acts and all these eventual consequences (see Skinnider, 2011; Hall, 2013). The failure of criminal justice systems to adequately tackle corporate victimization as a whole is another related concern (see Gobert, 2008).

Even when criminal justice processes do achieve convictions in cases of environmental harm, judges have traditionally been somewhat ill-equipped to pass sentences which fully reflect the scale of the harm caused by reason of lack of experience in this area coupled with a lack of access to clear sentencing guidelines (see O'Hear, 2004). In more recent years, progress has been made in this regard with many jurisdictions introducing specific guidance to sentencers in environmental cases (see Sentencing Council, 2014). For example, Faure et al. (2016) note that the use of minimum sentences in the case of wildlife crimes is now relatively widespread, at least across the European Union. In terms of the proportionality of such sentencing exercises, this report also points to a growing awareness among judges that both trafficking of waste and wildlife crime impacts on wider society 
and the security of citizens indirectly by allowing crime and black economies to grow. Less positively, however, Huisman et al. (2015) note that penalties for the illegal trade in e-waste vary greatly both within and between jurisdictions in terms of monetary fines and prison durations. In general, the authors conclude that participation in such illegal activities does not appear risky to offenders due to the low probability of being prosecuted and sentenced.

More generally, Gerstetter et al. (2016) have argued that, at an international level, problems remain in gaining access to reliable information on the degree of sentence awarded in environmental cases by different courts in different jurisdictions that would allow a degree of cross-calibration to occur. This report also indicates that relatively low-level fines remain the norm for environmental crimes, even where the damage caused appears to be significant. Of course, this raises the key question of how sentencers might learn of the "full" range of harm impacting on victims in individual cases and tailor their actions accordingly. For other kinds of crime it has become common for courts to utilize so-called victim impact statements, although the degree to which these in fact influence sentences is debated (see Erez, 2000). In the environmental sphere, greater difficulty also lies in identifying the full range of "victims" to be "consulted" on such issues especially when, as demonstrated later in this article, human victims may not themselves associate harm they are suffering with any particular legal transgression, or even be aware of it. Expanding this discussion to nonhuman animal victims as well as the notion of the environment itself being victimized (see White, 2013), we can appreciate the challenges faced by traditional criminal justice process in attempting to adequately reflect this full range of harm in a sentence.

The above observations of course raise fundamental questions concerning what criminal justice systems should be doing in relation to environmental victimization. Is the purpose of these systems to "punish" offenders to a degree proportionate to the full range of harm which flows from their offending activity, inkeeping with a so-called "just deserts" approach? (Carlsmith et al., 2002) Perhaps the goal of such a system is to compel offenders to provide redress (financial or otherwise) for all the losses incurred by human and nonhuman victims, as well as working to repair the damage done to the ecosystem as a whole. Another possibility is that such processes should, as a minimum, offer official acknowledgement of the full range of harm perpetrated by environmental crimes, both as a cathartic measure for those (human) victims affected and to reinforce the social message that such harm is taken seriously. Certainly, the wider victimological literature consistently points to the significance to victims of having their victimization acknowledged by a court, regardless of the specific sentencing outcome (Shapland et al., 1985).

One response to the above points might be that it will always be impossible for criminal justice process to recognize, by any of the means suggested above, the full range of harms elicited by environmentally offending behaviour. This is because such processes can only ever encompass clearly defined forms of harms susceptible to high degrees of objective proof and a clear chain of causation. Taken as such, the system's apparent inability to consistently recognise, prosecute or sentence in cases of environmental harm in fact reflects the reality that such harms are beyond the proper remit of the criminal justice system. Williams (1996), in putting forward the definition of environmental victims discussed above, intentionally grounded that understanding on the notion of "injury" rather than "harm". The author argued that this was the only viable starting point if the goal was to develop functioning legal systems around environmental victimization, especially in criminal justice, as the concept is more objective and measurable. In so doing Williams emphasized the "limits of law" in addressing wider forms of environmental harm, which he argued were ultimately subjective. At the same time, however, Williams also emphasized what he saw as an "obvious need for social justices to parallel formal legal processes" (p. 200) to address broader forms of environmental harm. In this, we find the first suggestions that alternative mechanisms to the formal criminal justice process might offer something more to environmental victims. Later sections of this article will proceed to argue that a more cultural understanding of environmental victimization implies that restorative justice and mediation approaches specifically might offer some of the therapeutic and practical redress outcomes to human and nonhuman victims, which have been alluded to above.

The last point notwithstanding, other commentators have been less willing to accept as a given the kind of limits to the criminal justice process discussed. In the broader victimological field, the cause of wider categories of human and nonhuman environmental victimization was given greater impetus by the development of critical victimology and its expanded notions of victimhood beyond simple, criminal classifications (Hough, 1986; Dignan, 2004). Indeed, in many ways, the human, and nonhuman, victims of environmentally polluting events fall squarely within the conceptualization of "real, complex, contradictory and often politically inconvenient victims" (Kearon and Godfrey, 2007: 31) with which the critical critique is so concerned.

For these critical scholars, the apparent inability of the criminal justice process to address such victimization is in fact grounded in societal power inequalities. As noted by Ruggiero and South (2010):

\begin{abstract}
"the high status of those causing the most harm who (like other powerful offenders) frequently reject the proposition that criminal definitions should apply to them while constantly striving to persuade legislators that the imposition of norms of conduct on them would be detrimental to all” (p. 246)
\end{abstract}

The notion that various socially harmful activities fail to be criminalized as a result of power inequalities, and especially the influence of large corporations on law and policy, has particular resonance in the environmental sphere. As Gibbs et al. (2010) have put it:
"A grey area emerges for environmental risks that are not currently subject to regulation or criminal enforcement but where further understanding of the risk may lead stakeholders to argue for regulation and/or criminaliza- tion" (p. 133)

Passas (2005) refers to the wide range of legally permissible but environmentally destructive activities conducted by corporations with the implicit or explicit consent of states as "lawful but awful" and, in focusing specifically on environmental victimization, Skinnider (2011) notes:

\begin{abstract}
"many environmental disruptions are actually legal and take place with the consent of society. Classifying what is an environmental crime involves a complex balancing of communities' interest in jobs and income with ecosystem maintenance, biodiversity and sustainability" (p. 2)
\end{abstract}

Examples of cases where large-scale environmental destruction and harm caused to human and nonhuman animals, as well as the ecosystem a whole, has escaped the attention of the criminal justice system abound in the green criminological literature and 
include infamous cases such as the 1984 Bhopal gas leak in India (Walters, 2009), the 2010 Gulf of Mexico Oil Spill (Uhlmann, 2011) and the ongoing First Nation resistance to corporate exploitation of tar/oil sands in Alberta, Canada (see Smandych and Kueneman, 2009).

Such debates have led many commentators to think not in terms of environmental crime but rather of environmental "harm". Again, this development in the green criminological ligature is grounded in broader critical criminological ideas. Thus, Hillyard and Toombs (2003) advocate criminologists pursuing a "social harms approach". It is clear that focusing on harm rather than crime has the potential to include more legally ambiguous activities, which foster victimization. Indeed, even when such activities are criminal in the strict legal sense, focusing on harm allows us to account for such activities in cases where whatever mechanisms of justice that are available fail to adequately recognize, prosecute or adequately reflect such transgressions in their sentencing practicalities. The social harms approach also poses a challenge to individualistic conceptions of crime grounded around notions of risk (Giddens, 1990). The prevalence of large-scale "community victimizations" (Bhopal, the Gulf of Mexico, Lac-Mégantic and so on.) in the environmental sphere makes this focus on group victimization particularly attractive.

Refocusing the debate on "harm" rather than "law" allows us to consider critically the goals of the criminal justice process when it comes to environmental crime. In particular, it allows us to consider whether that system should be more focused on restoration and compensation to human and nonhuman victims, as suggested above. The difficulty from an environmental perspective, however, is that the social harms approach advocated by Hillyard and Tombs, as well as the critical victimological approach more generally, has up until now been largely anthropocentric in its focus, ignoring the wider issue of ecological justice (acknowledging that humans are just one part of a complex ecosystem) and also animal and species justice (see White, 2013). In addition, the critical approach has tended to view "harm" as a static impact when, in reality, the impact of environmental harm on victims of all kinds is often highly dynamic and changeable over time. It is these limitations to the critical and social harms approaches as presently conceived which, it is argued, necessitates a move beyond these debates to encompass more cultural perspectives, to which this article now turns.

\section{Cultural victimology}

It has become increasingly clear in recent years that our understanding of "victimization" is informed by a whole range of societal and political factors, which extend well beyond its legal definitions. Recently, debates in victimology as a whole have thus taken a more cultural tone. At the forefront of this development, McGarry and Walklate (2015) characterize such "cultural victimology" as broadly comprising of two key aspects. These are the wider sharing and reflection of individual and collective victimization experiences on the one hand and, on the other, the mapping of those experiences through the criminal justice process. Through both these mechanisms, wider definitions of "victimization" become culturally embedded to the point where policy makers are prompted to respond with more targeted reform. One widespread example of this is the progression of domestic violence over the decades from being perceived both by the public and by the criminal justice system as a "normal" aspect of family life, or at least something, which the state should not become involved with (Cretney and Davis, 1997), to one where significant legal and policy reform has occurred in many jurisdictions. This has facilitated a more effective criminal justice response to what as a result is now widely recognized as a "real" and "serious" criminal victimization, which at the time of writing is receiving fresh attention by the UK government (see Prime Minister's Office, 2017). In fact, however, the cultural relationship is reciprocal, as acknowledgement of harm by a criminal justice process is itself thought to be extremely powerful as a signal to wider society that a particular kind of activity or harm is now socially (and culturally) unacceptable (Dignan, 2004).

I have previously drawn upon the work of Hans Boutellier (2000), whose discussion of victimization and morality in a secular society to some degree foreshadowed this cultural trend (Hall, 2013). Boutellier (2000) argued that, as the process of secularization goes on, common standards of morality decline but common appreciation and sympathy for the impacts on those who have suffered harmed remains and takes over as a shared moral barometer for society. In more recent parlance, we could say that such victimization becomes incorporated into the fabric of our social culture.

In the green criminology literature, White (2011) has touched on these ideas directly in relation to environmental victimization through emphasizing the socio-cultural context of understanding and responding to environmental harm:

"Ultimately the construction of (environmental) victimhood is a social process involving dimensions of time and space, behaviours involving acts and omissions, and social features pertaining to powers and collectivises" (p. 122)

As further noted by White, this state of affairs reflects "one of the truisms of victimology that being and becoming a victim is never socially neutral" (2011: 111). Central to the cultural approach to victimization, therefore, lies an understanding of victimhood as a dynamic and changeable concept in terms of the meanings attributed to it both by the public at large and (in the case of humans) by the individual or collective set of victims themselves. It is this recognition that has driven many contemporary victimologists to think in terms of "trauma" rather than "injury" or "crime" because trauma often develops over time and in directions sometimes many steps removed from the initial act (criminal or otherwise) that initiated the victimization (Hall, 2013).

Another significant aspect of cultural victimology is the notion of "mapping" victimization though the criminal justice (or other) process. The early 1990s saw an explosion of academic interest in the way human beings interpret and ascribe meaning to disturbing life experiences by recounting them in the form of stories (Maines, 1993; Plummer, 1995; Orbuch, 1997). The findings of Orbuch et al. (1994) for example demonstrate the value of narrative account-making activities in the context of sexual abuse, the authors summarizing the forms and benefits of account-making to victims as:

"expressing emotions about the assault; cognitively clarifying aspects of the assault; resolving some of the resultant anger, fear, and paralysis of action; and actually moving on with one's life constructively" (p. 261)

The proposal that victims may engage in such a process through their participation in the criminal justice process, and thereby derive therapeutic outcomes, has been the subject of a dedicated literature usually labelled "therapeutic jurisprudence" (Wexler and Winick, 1996; Rottman and Casey, 1999; Stolle, 2000). The cultural approach to victimology supports such ideas in emphasizing the needs of victims to adequately map their experiences, which for them develop over time. Herein, however, lies a key difficulty with most formal criminal justice processes, 
and especially the adversarial justice model used in many Common Law jurisdictions. Such systems actively discourage victims when appearing as witnesses from elaborating on the developed state of the harms they have suffered beyond the confines of their pre-prepared witness statement (see Luchjenbroers, 1996). It is in this sense that cultural victimology starts to point to the advantages of more restorative or mediationbased processes.

Restorative justice mechanisms in various forms have been widely debated by both victimologists and criminal justice commentators for many years. As a concept, restorative justice has been variously defined with one of the most widely used understanding still deriving from that of Marshall (1999):

"Restorative justice is a process whereby all the parties with a stake in a particular offense come together to resolve collectively how to deal with the aftermath of the offense and its implications for the future" (p. 5)

Restorative justice is in part intended to afford victims some of the key outcomes of account-making along with the therapeutic effects advocated by Wexler and Winick (1996) and others, as well as reaching "better" sentencing outcomes and affording victims a genuine participatory role within the justice process (see Edwards, 2004). As such, restorative justice gives (human) victims the capacity to express themselves much more openly than in the formal criminal justice process and, in so doing, explore the wider consequences of particular crimes. This may in turn result in an agreement between all parties for offenders to provide redress. In so-doing, victims are also afforded the "account-making" opportunities from which they may derive catharsis and the basic recognition that the formal criminal justice system is unable to provide but which the victimological literature suggests victims are keen to have, perhaps even above more compensatory or retributive outcomes (Dignan, 2004). Perhaps most tellingly, research from Shapland et al. (2006) reveals that restorative justice processes bring significant advantages to victims of crime in terms of satisfaction and perceptions of procedural justice.

Information concerning the application of restorative processes to cases of environmental harm is scant and mainly anecdotal in nature, although the growing evidence of its uses for victims of other crimes makes this an area worthy of detailed research. There is, however, a small but growing literature on what has been variously termed "environmental mediation" and "environmental alternative dispute resolution" (ADR) (see Edwards, 1985). As with "mediation" as applied to restorative justice options, the term is variously defined, although one concise definition is provided by Amy (1983):

"Put most simply, environmental mediation is a process in which representatives of environmental groups, business groups and government agencies sit down together with a neutral mediator to negotiate a binding solution to a particular environmental dispute" (p. 1)

Of course, this definition in fact excludes environmental victims directly, which in itself is quite telling of an article devoted to the issue of environment degradation. In fact, victims themselves feature relatively little in this literature, with much more of the discussions revolving around the role of "environmentalists" or "environmental groups". The extent to which such groups represent real victims of environmental harm is a moot point. Fundamental questions also revolve around how the "accounts" of nonhuman animals or the environment itself might figure in any adapted version of such mediation processes. The next section will, therefore, turn to discuss how cultural ideas might further the agendas of green criminology and victimology specifically.

\section{Cultural environmental victims}

Pursuant to the cultural victimological approach outlined above, a range of conceptual tools were identified which, it is argued, have thus far been underutilized by green victimologists. In particular, these include drawing on the concepts of account-making, collective victimization and trauma. Furthermore, it was argued that cultural understandings of victimization might imply that environmental victims, those that are human at least, may derive significant benefits from more restorative or mediationbased processes. To help illustrate how ideas like these might transpose to the environmental sphere this article will draw upon a specific case study: the Lac-Mégantic train disaster of 2013. In this case, a free-running unsupervised freight train derailment as it rolled at high speed through the city of LacMégantic in Quebec, having been left without sufficient breaks. The train was transporting over 6,000,000 litres of crude oil, much of which was spilled when the train came off the lines and subsequently seeped into the ground, local rivers and lake. The fire resulting from the spill took 2 days to extinguish, creating a toxic cloud over the town bringing soot fallout, oil vapours and dust. Over 30 buildings were destroyed and local water and food supplies became contaminated. There were 47 (human) fatalities in the immediate aftermath. Broader impact on nonhuman animals and the environment as a whole has not been categorially assessed, but has been estimated to be significant (CBC News, 2013).

Longitudinal research carried out by Généreux et al. (2014; Généreux, 2017) into the tragedy reveals a complex web of interrelated impacts, which developed for years after the disaster. Généreux's work is restricted to human impacts and, as such, represents very much the tip of the iceberg in terms of the full nohuman or environmental outcomes of the event. The author splits these impacts into three broad categories: human losses (fearing for one's life or that of a loved one, losing a loved one, suffering injuries); material losses (relocation, loss of employment, property damage) and negative perceptions (perception of the event as having been stressful, as having adverse effects in the future, as having interrupted something important, or as having caused the loss of something important). The study involved repeat interviews with a sample of around 800 people who reported one or more of the above-named impacts and were carried out in 2014, 2015 and 2016. The results indicated high prevalence of post-traumatic stress disorder, general anxiety and depression among this population, and also high levels of substance misuse which increased with individuals who had been exposed to more of the impacts.

Perhaps most significantly, the longitudinal element of Généreux's study indicates that "more than 3 years after the disaster, direct victims as well as the general population of LacMégantic still suffer" (Généreux, 2017). Many respondents had experienced "limited improvement from 2014 to 2016" and were in fact demonstrating higher levels of post-traumatic stress disorder in 2016. Some of these escalated levels of trauma had been caused by secondary stressors such as the major reconstruction of the town and the resumption of train services through the locale, which were reported to cause great distress to some residents. As the Regional Director of Public Health for the area as well as an academic commentator on it, Généreux (2017) emphasizes the significant role of emergency response and disaster management teams in supporting those affected by the disaster. In particular, Généreux highlights the importance of long-term monitoring programmes assessing victims' physical 
and mental health impacts. This of course also implies that poor management of an environmental disaster situation by such agencies might exasperate such traumas.

In the Lac-Mégantic case, as in many other high-profile environmental disasters stretching back at least to Bhopal, one sees the tendency for collective expression of victimization by the community, as demonstrated by community and "survivor" support groups and anniversary events marking the incidents. ${ }^{1}$ One also sees collective expression- "mapping"-of the harm endured through the pursuit of class law suits, as well as the broad support in the community for criminal action (specifically criminal negligence charges) to be brought against the train conductor, who has become the focus of profound and collective local enmity (see Gilis, 2013).

Perhaps key to the value of a cultural understanding of LacMégantic as an ongoing environmental victimization lies is the fact that, at the time of writing, the legal processes are still taking place to determine whether or not the incident itself, or any preceding errors on the part of the train companies or the individual train managers and engineers, amount to crimes. As such, the "victimization" is recognized and expressed not as a result of any formal legal process or "official" labelling but as a result of the trauma suffered, the development of this trauma over time, and the expression of that suffering (and recovery) by residents. In keeping with the cultural notion of victimhood, it is notable that some of the "harms" suffered by these victims appear to be far removed from the original actions or inactions of train operators.

In the complex, multi-facetted and constantly changing dynamic of Lac-Mégantic, we might speculate on the degree to which the full range of harms vested on human and nonhuman victims, and the ecosystem as a collective, is likely to find expression though a formal criminal justice processes: assuming such a process ultimately gets underway at all. Again, this prompts us to consider the alternative of restorative justice or meditation, constituting what Williams called a parallel form of social justice. Through such a process victims may gain the means of expressing the broad range of harms they have experienced, which continue to develop. Furthermore, mediation models in particular often encompass representatives of whole communities affected by given harms (see Van Ness and Heetderks Strong (2014). In this sense, such a process arguably reflects the collective nature of this victimization far more accurately than a criminal trial where only the state and the defendants would be parties.

This assessment on the applicability of environmental mediation in Lac-Mégantic is supported by the findings of one of the first test cases of such a process from the USA. In this case, Gerald Cormick and Jane McCarthy of the University of Washington's Environmental Mediation Project were appointed by the governor of Washington State to serve as mediators in a dispute between environmentalists, farmers, developers and public officials over the damming of the Snoqualmie River. According to Shmueli and Kaufman (2006) "the resulting agreement illustrated one of mediation's main assets-its capacity to generate creative solutions that satisfy the interests of all parties involved" (p. 17). Certainly, the adaptability of mediation and other restorative options is a big plus, especially given the longstanding criticisms of mainstream victimology that criminal justice reforms aimed at victims tend to assume specific victim characteristics and needs. As noted by Shmueli and Kaufman (2006):

"Each environmental conflict has a unique cast of characters, a history unlike any other except in broad strokes, a singular pattern of resources, interrelationships among parties, a special set of issues and a unique set of moves that defies simple classification and comparison" (p. 20)

Furthermore, Matsumoto (2011) notes that mediation is a fitting solution for a situation in which, as in many environmental pollution disputes, "the polluter and its victims are located near each other and will remain in place and maintain an on-going relationship after their dispute is resolved" (p. 660).

Of course, what is clearly missing from this picture is the perspective of nonhuman victims and the ecosystem itself, both of which have escaped detailed attention in relation to the LacMégantic tragedy as a whole. This aspect will be discussed below and is developed from the work of Flynn and Hall (2017).

Culturally embedding nonhuman victims and ecological harm. Beirne and South (2007) have argued that if society is going to concern itself with some environmental harms, then the impact on nonhuman animals cannot be separated from this endeavour:

"Animals of course live in environments, and their own well-being-physical, emotional, psychological-is absolutely and intimately linked to the health and good standing of their environments" (xiii-xiv)

This implies that whenever we are talking about harm to the environment we are necessarily talking about the victimization of nonhuman animals and to the ecosystem itself. In these terms the continued anthropocentric bias of victimology, and certainly green victimology, seems unjustifiable. This view is supported (if indirectly) by Boutellier's thesis discussed earlier in this article. While Boutellier's construction is itself anthropocentric (only the suffering of or harm caused to humans is considered) it is argued that there is no reason why the focus on harm-"the suffering of others"-cannot equally apply to a greater appreciation of the suffering of other species and indeed harm to the environment itself. This is not of course to suggest that green criminology has not made significant strides towards the wider incorporation of nonhuman and nonanimal victims sans the cultural perspective. White (2008), in following a more holistic approach to green criminology has criticized some aspects of the predominant environmental justice perspective for ignoring the wider issues of ecological justice and species justice introduced at the start of this article. White's understanding of "ecological" encompasses "conservations of specific environments, animal rights and preservations of the biosphere generally" (p. 39), or some combination thereof. For White, an important step towards incorporating such perspectives within green criminology is to promote the concept of ecological citizenship, which for him would incorporate both environmental justice and ecological justice concerns, placing humans as part of (but equal to) the environment around them. Similar themes are also prevalent in the work of Benton (2009), who examines the Implications of the "green agenda" for varying conceptions of "social justice". Taking four key components of the green challenge-natural limits on the scale of human activity imposed by nature; the drive for animal/human continuity; non-anthropocentric values and notions of ecotopia-Benton evaluates the implications of these challenges for both formal (equated here with Rawlsian (see Rawls, 1999) and communitarian theories of justice. His analysis demonstrates the multiple challenges posed to existing conceptions of justice, but also how justice principles challenge the foundations of the green agenda. He concludes that "If anything, the green challenge requires us to give still more attention to the question of justice, as well as providing new work for the concept 
and principles of justice to do...the requirement to conceptualize justice across species is perhaps the most testing of all" (p. 29).

Culturally, there is arguably greater public awareness of the damage being done to the nonhuman components of the environment than at any time in the recent past (Molloy, 2011). This is exemplified recently by the widespread public outrage expressed at incidents such as the killing of a healthy giraffe ("Marius") and four lions at Copenhagen zoo (Independent, 2014). The plight of certain nonhuman animals also attracts much more media attention, with some instrumental impact on cultural attitudes. For example, media coverage of food production practices is thought to influence demand for some meats in the USA (Tonsor and Olynk, 2010). As noted in the previous discussion of the cultural victimological approach, such cultural recognition might be seen as a precursor to more significant action on the part of policy makers, while the recognition of such issues by formal juice mechanisms might well feed back into the wider development of such cultural understandings.

Conceptual and cultural arguments aside, it is nevertheless clear that much less attention has been focused on the incorporation of less anthropocentric perspectives within criminal justice or indeed within restorative justice and mediation procedures. On the latter point, which is key for the purposes of the present discussion, we have seen that while such alternative social justice mechanisms may well bring distinct advantages to human environmental victims, at worst we may be concerned that these processes will effectively serve to marginalize nonhuman and ecological damage. For example, if through a mediation process human victims (whether individually or collectively) negotiate restitution payments from a corporate polluter, how can such process ensure this does not divert funds from wider ecological restoration projects, resulting in a net-loss to the ecosystem as a whole? One solution is to incorporate representation of nonhuman and ecological interests within such a mediation process. Such ideas were tested in 2011 when the Supreme Court of the United Kingdom staged a mock trial for the as-yet non-existent international crime of ecocide. The goal of the project was to test the suitability of restorative justice as a means of sentencing offenders for environmental crime. On this point, Rivers (2012) notes:

"The experiment proved that there is real potential for using restorative justice in conjunction with ecocide. It enables dialogue, understanding, healing and creativity to emerge. It is about making whole again rather reinforcing separation and fragmentation through punishment of perpetrators and exclusion from the process of victims" (p. 18)

As highlighted above, this exercise incorporated specific advocates to speak for nonhuman environmental victims and for the environment itself. The future potential for further development of the restorative approach, particularly in regard to case disposal, is, therefore, clear. This being the case, the final substantive section of this article will turn to focus on arguments and evidence concerning environmental mediation and the application of restorative justice in environmental cases more specifically.

\section{Environmental mediation and restorative approaches to environmental victimization}

This article has sought to ground its study of environmental victims within broader cultural victimological debates. As a result of this exercise, the argument has been made that restorative justice and mediation-based approaches might well offer more to victims of environmental harm than traditional criminal justice processes are ever likely to do, at least in the medium-term. In particular, we have noted that mediation seems better suited to the facilitation of an account-making exercise incorporating much broader and more removed instances of victimization associated with environmental crime, and indeed broader environmental harms not specifically recognized by the criminal justice system. We have noted that such processes may also encompass more meaningfully the collective nature of much environmental victimization as well as the more dynamic characteristics of this harm, as a developing trauma, as encapsulated by cultural victimology. Although such process are traditionally geared around human victimization, it was noted in the last section that adapting these to incorporate more nonhuman and ecological perspectives is possible, if experimental.

Following on from the last point, very little of the admittedly scant literature on this subject encompasses discussion of nonhuman victims. Much of the literature concerning environmental mediation is US-based, which of course is a disadvantage given that it is nations of the global south and their people who tend to fall victim to environmental harm (South, 2010). Indeed, many such studies focus on the cost savings frequently associated with such processes compared with criminal justice resolutions, as well as the alleged shorter timescales (see Mernitz, 1980). In fact, very little detailed empirical evaluation has been done to test these claims. One exception is that of Sipe (2007) who demonstrates via quantitative analysis that environmental mediation does produce a statistically significant increase in settlement rates, when compared with civil law actions, but no difference in compliance rates with these agreements. Again, it is notable that Sipe's analysis fails to mention the human or nonhuman victims of environmental harm directly.

One of the few studies to examine environmental mediation empirically as well as to discuss the position of the victims in that process directly is that of Matsumoto (2011). Referring to "environmental alternative dispute resolution (ADR)" Matsumoto suggests that when environmental victims engage representation, or collectively group together in an effort to increase bargaining power, this in fact complicates the process to the extent that it becomes more cumbersome:

"Far from the conventional expectation that representation hastens the resolution of environmental disputes, our empirical results suggests ADR becomes less effective when many agents are involved" (p. 665)

Certainly, environmental mediation is thought to bring difficulties as well as advantages, not least of which is the fact that "those who have the time and resources to participate in a mediation process are not necessarily representative of the interest groups affected by the decisions issuing from this process" (Shmueli and Kaufman, 2006: 21). This might be especially true given the low economic and social standing of many victims of environmental harm (South, 2010), which returns us to a point alluded to earlier in this article that "environmentalists" or "environmental groups" may not always be representing the interests or needs of real environmental victims. In fact, examples of environmental mediation in the USA seem to differ from Japan in this regard, where Matsumoto (2011) cites statistics indicating that $82 \%$ of complaints are filed by a pollution victim or by his or her family members. That said, in Japan a system of environmental mediation has been adopted by the public authorities, whereas in the USA these are usually private schemes, consequently access to solid data in the former country is more forthcoming. 
Amy (1983) further discusses the opinion expressed in some critical quarters of environmentalism that mediation in fact panders to the benefit of big industry and the polluters themselves. Thus, the author contends, most environmental mediation actually takes place in a context of palatable political bias, power imbalance and the illusion of voluntariness. For example, Dryzek and Hunter (1987) have suggested that in the aftermath of the Indian Bhopal disaster, Union Carbide was in fact very keen to engage in attempts by Environmental Mediation International to establish a good compensation scheme rather than going down more legalistic routes. While Amy (1983) is generally more hopeful for the overall benefit of mediation in these cases, he still injects a note of caution into his conclusion:

"There is no simple answer. As a rule, it would benefit environmentalists to have a healthy suspicion of mediation, especially when the offer to mediate comes from their opponents" (p. 19)

Of course, this is a rather pessimistic interpretation of the motives of corporations wishing to enter into environmental mediation. An alternative suggestion is that mediation and ADR is in fact the usual manner in which corporations resolve conflicts with each other, and thus it may simply be the route with which they are most familiar.

Overall, the cause of restorative justice in environmental cases, along with that of environmental mediation, is at present severely held back by a lack of quite basic empirical data concerning the nature of the settlements (including much information about the compensation agreements reached), the processes used and the effectiveness/enforcement of these agreements. Without such information, it is very difficult to test the more alarmist claims of power imbalances and so on. It is also problematic that the majority of information we have comes only from industrialized countries which, as noted previously, simply do not bear the brunt of environmental victimization. Even within these countries environmental victims will tend to be especially marginalized groups, lacking power or social standing. The concern then is that such groups lack the political or social capital to meaningfully influence a mediation exercise when the other side of the table is dominated by large multinational corporations, and perhaps their own state. In such instances, it is suggested that victims may well need the guarantees and protections (and the enforcement power) of formalized justice systems (whether criminal or civil). There is also a further complication in that the literature that exists on environmental mediation, when it mentions victims' difficulties at all, fails to consider the possibility of multiple groups of victims with competing interests. As noted already, this literature also largely eschews a non-anthropocentric perspective.

\section{Conclusions}

The purpose of this article has been to draw together the development of cultural victimology and that of green criminology as a means of better understanding environmental victimization as a concept on the one hand, as well as to critically assess and test the limits of most formal criminal justice processes in responding to such victimization on the other. In so doing, is has been shown that environmental victimization, with its group harms, long-term and changing impacts and developing traumas, seems to fit the cultural conceptualization of victimhood far better than it does with more traditional "legalistic" notions of victimization based on staunch causation principles. Furthermore, it has been shown that a cultural approach to environmental victimization affords a much fuller understanding of the issues facing environmental victims in criminal justice processes than the empiricist "applied science" orientation of radical and critical criminologies.

It should be emphasized that as an undertaking green criminology has always lacked a definitive theoretical standpoint shared by all those who call themselves "green criminologists". Labelling a subject area "green criminology" is useful in that it might signify a set of assumptions, theoretical underpinnings and methodological issues. As ever, however, such classifications are just labels, the meanings of which are in constant flux, especially in such a new and rapidly evolving area. Indeed, for his part White (2013) has commented that "there is no green criminology theory as such (p. 22) and that "those who are doing green criminology define it in ways that best suit their own conception of what it is they are doing" (p. 17). For him, therefore, the real benefit of the label lies mainly as a focal point for people interested in environmental crime, harms and risks. It is in the spirit of this "open" nature of green criminology that this article offers the cultural victimological approach as a significant addition to the toolkit of green criminologists, particularly those seeking to interrogate the specific impact of environmental harm on victims and the responses of criminal justice and other processes. The cultural approach, it is argued, encompasses a number of theoretical perspectives that can help us better understand the shortcomings of criminal justice approaches to green harm, especially as they relate to complex instances of longterm and developing victimizations, which more positivistic and legalistic classifications of harm often fail to encompass. Fundamentally, therefore, the cultural approach offers a more constructivist account of the injuries vested on human and nonhuman animals, as well as the environment itself: one that is grounded on long-term sociological and psychological understandings of trauma and the meanings we associate with different forms of harm.

One significant outcome from this application of a cultural approach to environmental victimization is that it has provided a strong theoretical basis for advocating the wider use of restorative justice and mediation mechanisms as a forsm of alternative (or parallel) social justice in the light of the shortcomings of the formal criminal justice process. Through such mechanisms, it has been argued, human victims may gain opportunities to express the full range of harms vested upon them by environmental offenders and in so doing arrive at an outcome, which better acknowledges the harm done. Further, we have seen that such victims may gain certain therapeutic benefits from this exercise, freed from the evidential and procedural constraints of the criminal justice process. That said, it is also clear that the theory concerning what environmental victims stand to gain though such processes are in dire need of substantiation through detailed and focused research. Among the most pressing needs in this regard is to determine how best to incorporate the perspectives of nonhuman victims and the ecosystem as a whole into these processes. Without this central addition, it is argued, any process ostensibly aimed at better addressing "environmental victimization" will remain fundamentally flawed.

\section{Note}

1 In one example, as a collective expression of healing and "to show that there is still joy and good humor in this city" a collection of residents recreated a popular music video and posted it online (available at: https://www.youtube.com/watch?v=9eBwDzJm7_0)

\section{References}

Amy D (1983) The politics of environmental mediation. Ecology Law Quarterly; 11 (1): $1-19$

Benton T (2009) Rights and justice on a shared planet: More rights or new relations?. In: White R (ed). Environmental Crime: A Reader. Willan: Cullompton, pp 51-175. 
Beirne P and South N (2007) Issues in Green Criminology: Confronting Harms Against Environments, Humanity and Other Animals. Willan Publishing: Cullompton.

Boutellier H (2000) Crime and Morality: The Significance of Criminal Justice in Post-Modern Culture. Kluwer: AA Dordrecht.

CBC News. (2013) Lac-Mégantic an 'environmental disaster,' says expert [online]. Available at http://www.cbc.ca/news/canada/montreal/lac-m\%C3\%A9gantican-environmental-disaster-says-expert-1.1858090, accessed 18 May 2017.

Carlsmith K, Darley J and Robinson P (2002) Why do we punish?: Deterrence and just deserts as motives for punishment. Journal of Personality and Social Psychology; 83 (2): 284-299.

Cretney A and Davis G (1997) Prosecuting domestic assault: Victims failing courts or courts failing victims? Howard Journal of Criminal Justice; 36 (2): $146-157$

Dignan J (2004) Understanding Victims and Restorative Justice. Open University Press: Maidenhead.

Dryzek J and Hunter S (1987) Environmental mediation for international problems. International Studies Quarterly; 31 (1): 87-102.

Edwards H (1985) Alternative dispute resolution: Panacea or anathema. Harvard Law Review; 99 (3): 668-684.

Edwards I (2004) An ambiguous participant: The crime victim and criminal justice decision-making. British Journal of Criminology; 44 (6): 967-982.

Erez E (2000) Integrating a victim perspective in criminal justice through victim impact statements. In: Crawford A and Goodey J (eds). Integrating a Victim Perspective Within Criminal Justice: International Debates. Ashgate Dartmouth: Aldershot165-184.

Faure $\mathrm{M}$ et al. (2016) Conclusions and Recommendations. Available at: http://efface. eu/sites/default/files/publications/EFFACE_Conclusions_recommendations.pdf.

Flynn M and Hall M (2017 forthcoming) The case for a victimology of nonhuman animal harms. Contemporary Justice Review.

Généreux M (2017) 'Consequences of Environmental Harm: The Case of The Lac Mégantic train derailment disaster'. Presentation delivered at the Transnational and International Environmental Crime: Synergies, Priorities and Challenges Symposium, University of Lincoln, UK, 15th February 2017.

Généreux M et al. (2014) The public health response during and after the LacMégantic train derailment tragedy: A case study. Disaster Health; 2 (3-4): $113-120$.

Gerstetter C et al. (2016) Synthesis of the Research Project "European Union Action to Fight Environmental Crime" (EFFACE). Ecologic Institute: Berlin.

Gibbs C, Gore M, McGarrell E and Rivers L (2010) Introducing conservation criminology: Towards interdisciplinary scholarship on environmental crimes and risks. British Journal of Criminology; 50 (1): 124-144.

Giddens A (1990) The Consequences of Modernity. Polity Press: Cambridge.

Gilis W (2013) 'Is Tomr Harding a Villain or Victim?', The Star. Available from: https://www.thestar.com/news/crime/2013/09/06/is_tom_harding_a_villain_ or_victim.html, accessed 19 February 2017.

Gobert J (2008) The corporate manslaughter and corporate homicide 2007: Thirteen years in the making but was it worth the wait? Modern Law Review; 71 (3): $413-463$

Hall M (2013) Victims of Environmental Harm: Rights, recognition and redress under national and international law. Abingdon: Routledge.

Hillyard P and Toombs D (2003) Introduction. In: Hillyard P, Toomb D and Pantazis C (eds). Beyond Criminology: Taking Harm Seriously. Pluto Press: London, pp 1-9.

Hough M (1986) Victims of violent crime: Findings from the first British crime survey. In: Fattah E (ed). From Crime Policy to Victim Policy. Macmillan: Basingstoke, pp 117-132.

Huisman J et al. (2015) Countering WEEE Illegal Trade (CWIT) Summary Report, Market Assessment, Legal Analysis, Crime Analysis and Recommendations Roadmap, August 30, 2015, Lyon, France. Available from https://www.researchgate.net/publication/281344533_Countering_WEEE_lllegal_ Trade_CWIT_Summary_Report_Market_Assessment_Legal_Analysis_Crime_ Analysis_and_Recommendations_Roadmap.

Independent. (2014) Copenhagen Zoo that killed Marius the giraffe puts down four healthy lions. Independent, Tuesday 25 March. Retrieved 27 February, 2017, from http://www.independent.co.uk/news/world/europe/copenhagen-zoo-kills-fourlions-despite-outcry-over-death-of-marius-the-giraffe-9215375.html.

Kearon T and Godfrey B (2007) Setting the scene: A question of history. In: Walklate S (ed). Handbook of Victims and Victimology. Willan Publishing: Cullompton17-36.

Kirchengast T (2016) Victims and the Criminal Trial. Palgrave: London.

Luchjenbroers J (1996) "In your own words...": Questions and answers in a Supreme Court trial. Journal of Pragmatics; 27 (4): 477-503.

Lynch M (1990) The greening of criminology. Critical Criminologist; 2 (3): 1-5.

Maines D (1993) Narrative's moment and sociology's phenomena: Toward a narrative sociology. Sociological Quarterly; 34 (1): 17-38.

Marshall T (1999) Restorative Justice: An Overview. Home Office Research Statistics Directorate: London.
Matsumoto S (2011) A duration analysis of environmental alternative dispute resolution in Japan. Ecological Economics; 70 (4): 659-666.

McGarry R and Walklate S (2015) Victims: Trauma, Testimony and Justice. Routledge: Abingdon.

Mernitz S (1980) Mediation of Environmental Disputes. Praeger: New York, NY. Molloy C (2011) Popular media and animals. Palgrave Macmillan: London.

O'Hear M (2004) Sentencing the green-collar offender: Punishment, culpability, and environmental crime. The Journal of Criminal Law and Criminology; 95 (1): $133-276$.

Orbuch T (1997) People's accounts count: The sociology of accounts. Annual Review of Sociology; 23 (3): 455-478.

Orbuch T, Harvey J, Davis S and Merbach N (1994) Account-making and confiding as acts of meaning in response to sexual assault. Journal of Family Violence; 9 (2): 249-263.

Passas N (2005) 'Lawful but awful': Legal corporate crimes'. Journal of SocioEconomics; 24, 771-786.

Plummer K (1995) Telling Sexual Stories: Power, Change and Social worlds. Routledge: Abingdon.

Potter G, Nurse A and Hall M (2016) The Geography of Environmental Crime: Conservation, Wildlife Crime and Environmental Activism. Palgrave: London.

Prime Minister's Office. (2017) 'Prime Minister's plans to transform the way we tackle domestic violence and abuse'. Press release of 17th February. Available from: https://www.gov.uk/government/news/prime-ministers-plans-to-trans form-the-way-we-tackle-domestic-violence-and-abuse, accessed 19 February 2017.

Rawls J (1999) A Theory of Justice. Harvard University Press: Cambridge.

Rivers L (2012) Shareholder return- a 'Nuremberg defence'? Ecocide and restorative justice. Environmental Law \& Management; 24 (1): 17-19.

Rottman D and Casey P (1999) Therapeutic Jurisprudence and the emergence of problem-solving courts. National Institute of Justice Journal; Jul, 12-19.

Ruggiero V and South N (2010) Critical criminology and crimes against the environment. Critical Criminology; 18, 245-250.

Sentencing Council. (2014) Environmental Offences: Definitive Guidelines. Sentencing Council: London.

Shapland J et al (2006) Restorative Justice in Practice - Findings From the Second Phase of the Evaluation of Three Schemes, Home Office Research Findings 274. Home Office: London.

Shapland J, Willmore J and Duff P (1985) Victims and the Criminal Justice System. Gower: Aldershot.

Shmueli D and Kaufman S (2006) Environmental Mediation. The Center for Environmental Policy Studies Series no. 24 Center for Environmental Studies: Jerusalem.

Sipe N (2007) An empirical analysis of environmental mediation. Journal of the American Planning Association; 64 (2): 275-285.

Skinnider E (2011) Victims of Environmental Crime-Mapping the Issues. The International Centre for Criminal Law Reform and Criminal Justice Policy: Vancouver.

Smandych R and Kueneman R (2009) 'Ecological Criminology? Recasting the Role of Criminology in Responding to Humanly Created Ecological Harm'. Invited paper presented at the institute of Criminology School of Social and Cultural Studies, Victoria University of Wellington, Wellington, New Zealand.

South N (2010) The ecocidal tendencies of late modernity: Polnational crime, social exclusion, victims and rights. In: White R (ed). Global Environmental Harm: Criminological Perspectives. Willan Publishing: Cullompton, pp 236-240.

Stolle D (2000) Introduction In:Stolle D, Wexler D and Winick B (eds). Practicing Therapeutic Jurisprudence: Law as a Helping Profession. Carolina Academics Press: Durham, pp xv-xvii.

Tonsor G and Olynk N (2010) U.S. Meat Demand: The Influence of Animal Welfare Media Coverage. Kansas State University. Retrieved February 20, 2017, from http://www.ksre.ksu.edu/bookstore/pubs/MF2951.pdf.

Uhlmann D (2011) After the spill is gone: The Gulf of Mexico, environmental crime, and the criminal law. Michigan Law Review; 109 (8): 1413-1425.

Van Ness D and Heetderks Strong K (2014) Restoring Justice: An Introduction to Restorative Justice. Routledge: London.

Walters R (2009) Bhopal, corporate crime and harms of the powerful. Global Social Policy; 9, 324-327.

Wexler D and Winick B (eds) (1996) Introduction. In: Law in a Therapeutic Key. Carolina Academic Press: Durham, pp xvii-xv.

White R (2008) Crimes Against Nature: Environmental Criminology and Ecological Justice. Willan Publishing: Cullompton.

White R (2013) Eco-global criminology and the political economy of environmental harm. In: South $\mathrm{N}$ and Brisman A (eds). Routledge International Handbook of Green Criminology. Routledge: Abingdon, pp 243-260.

White R (2011) Transnational Environmental Crime: Towards An eco-Global Criminology. Routledge: Abingdon.

Williams C (1996) An environmental victimology. Social Science; 23 (1): 16-40, Reprinted in: White, R. (ed., 2009) Environmental Crime: A Reader, Willan Publishing: Cullompton, 200-22. 


\section{Data availability}

Data sharing is not applicable to this article as no datasets were generated or analysed.

\section{Additional information}

Competing interests: The author declares that there are no competing financial interests.

Reprints and permission information is available at http://www.palgrave-journals.com/ pal/authors/rights_and_permissions.html

How to cite this article: Hall M (2017) Exploring the cultural dimensions of environmental victimization. Palgrave Communications. 3:17076 doi: 10.1057/

palcomms.2017.76.
Publisher's note: Springer Nature remains neutral with regard to jurisdictional claims in published maps and institutional affiliations.

(c) (i) This work is licensed under a Creative Commons Attribution 4.0 cc. International License. The images or other third party material in this article are included in the article's Creative Commons license, unless indicated otherwise in the credit line; if the material is not included under the Creative Commons license, users will need to obtain permission from the license holder to reproduce the material. To view a copy of this license, visit http://creativecommons.org/licenses/by/4.0/

(C) The Author(s) 2017 